\title{
Friends with Values - The Impact of Reputable Lead Arranger and External Auditor on Borrower's Loan Terms
}

\author{
Bolortuya Enkhtaivan \\ Western Michigan University
}

\begin{abstract}
This paper explores the certification effect of both reputable lead bank, and external auditor on various syndicated loan terms - the yield spread, loan maturity, amount, and the number of covenants. The results from two-way interaction model support significant positive certification effects. In the presence of Top 10 lead arrangers, borrowers benefit from lower loan spread, reduced number of financial covenants, extended maturity, and larger loan amount. The relationship with a reputable external auditor elevates the certification effect. The study extends prior literature by analyzing non-price terms. The results suggest that for informationally disadvantaged parties, dual certification seems to add value.
\end{abstract}

Keywords: Information Asymmetry, Certification Effect, Loan Terms

\section{INTRODUCTION}

In loan contracts, borrower's negotiating power depends on the degree of information asymmetry and improves substantially if the borrower can validate its creditworthiness. However, the situation gets complex for syndicated loans that involve a group of lenders, rather than a single lender. In such cases, the borrower needs to convince the entire group where the information asymmetry is not uniformly distributed. While participant banks' responsibility might be limited to their loan share contributions, lead arrangers play more active roles. Lead arrangers receive loan application materials, conduct due diligence, pre-negotiate terms, invite other lending partners ex-ante loan initiations. After issuing the loan, lead arrangers monitor, receive and distribute payments to other members. Because of their constant contact with the borrower, and greater responsibilities, lead arrangers have access to private information of the borrower. On the other hand, syndicate participants are at the informationally disadvantaged position, and rely on lead arrangers' screening, and monitoring efforts.

How can a borrower certify its creditworthiness, particularly to informationally disadvantaged syndicate participants is an interesting question. Evidence suggests relationships with reputable agents bring value causing significant certification effects. The underwriting investment bank's reputation conveys crucial information about the issuing firm both to the stock market (Beatty \& Ritter, 1986; Carter \& Manaster, 1990), and the bond market (Fang, 2005). Also, the stock market reacts positively in events of loan announcements (Billett, Flannery, \& Garfinkel, 1995; Focarelli, Pozzolo, \& Casolaro, 2008; James, 1987; Lummer \& McConnell, 1989), and abnormal return increases for small, opaque firms (Slovin, Johnson, \& Glascock, 1992) and higher, if the lender is reputable (Billett et al., 1995). 
Above studies argue that the relationship with a reputable entity works as an effective signal. It is both costly and hard to imitate. For the owner, reputation has capital value like any brand names that it earned through consistent, high-quality services over time. Divergence to low-quality service is costly for the owner, not only destroying their brand capital but also losing its future businesses. Because of the high capital value, the reputation increases trust in service quality, decreases transaction, and monitoring costs. An opaque borrower with good faith and high, yet unobservable credit quality could build relationships with reputable agents to send positive signals to other stakeholders.

However, certification effects on syndicate loan terms are not well understood and show mixed results mainly with a focus on loan spread only. Some argue that it is beneficial to have prestigious lead arrangers in the syndicate that they can offer a lower spread (Do \& Vu, 2010; Ivashina, 2009). Ross (2010) highlights the dominance of three banks, Bank of America, J.P. Morgan and Chase and Citi, in the U.S. credit market, and documents that dominant banks offer about $0.3 \%$ lower loan spreads. He argues that lower spread is possible because of their economies of scale, as well as common knowledge and skills. In contrast, others argue that dominant lenders exploit their oligopolistic power and charge higher premiums (Cook, Schellhorn, \& Spellman, 2003; McCahery \& Schwienbacher, 2010). After controlling for self-selection bias, McCahery and Schwienbacher (2010) find increased loan spread for reputable lead arrangers. Their results are stronger ex-post banking deregulation that promoted mergers and acquisitions.

Another argument against the value of lead arranger's reputation is tied to its only partial claims from the loan. Lead arrangers who share loan rewards with other participant banks are susceptible to adverse selection, and moral hazard, especially if the share is in small portions. Therefore, would there be any cost-efficient certifier who might have no direct interest in the debt? Cen et al. (2016) document a significant positive effect of reputable principal customers in supply-chain relationships. Lenders recognize them, decrease loan costs, and reduce covenants if the borrower demonstrates a stable relationship with a reputable customer. Similarly, other studies (Chin, Yao, \& Liu, 2014; J.-B. Kim \& Song, 2011) emphasize auditor's value on debt contracting terms. They argue that high-quality auditors alleviate information asymmetry between lenders, and borrowers so they can influence on debt terms. When the external auditor is reputable, it reduces information costs for lenders, thus affects debt terms favorably.

In this paper, first, I explore the role of lead arranger's reputation on various syndicated loan termsthe yield spread, loan maturity, loan size, and the number of covenants. Second, I introduce the external auditor's identity measured by the Big 4 dummy. A relationship with reputable agents conveys valuable information to the information disadvantaged syndicate participants about the true quality of the borrower. Therefore, I empirically test the significance of the dual certification effect.

My results support the certification effect by finding more favorable loan terms for the borrower in the presence of Top 10 lead arrangers. The borrower benefits from lower loan spread, a fewer number of financial covenants, extended loan maturity, and larger loan amount. The presence of borrower's reputable (Big 4) external auditor improves the loan terms by bringing the added value of certification effect. A dual certification by both Top 10 lead arranger, and a Big 4 auditor reduces borrower's loan price by about $37 \mathrm{bps}$, decreases the number of financial covenants by about 0.2 units, and increases loan amount materially by approximately 121.3 million USD and extends the maturity by about a year longer. The results are robust to SUR estimation method after I count correlations among dependent variables, and use different measures for certification. Overall, results suggest that even for top tier lenders who possess higher monitoring capacity, certification by an independent third party could add informational value.

The study contributes to the literature in two ways. First, it examines the certification effect on loan non-price terms, including maturity, amount, and the number of covenants. In practice, debt covenants work as another form of ex-post credit monitoring. Consistent with it, Gilson and Warner (1998) report a relatively greater number of covenant restrictions for private loan markets as compared to public bond markets. Equally, loan amount and maturity are hard to negotiate terms, especially if the borrower possesses low bargaining power. 
Second, the study aims to better understand incremental value-added of both the lead arranger and the external auditor. Sundarasen et al. (2018) argue and find evidence of how dual certification by an underwriter and an auditor could affect IPO returns through different channels signaling distinct message to the market. While reputation in general increases trust in service quality and reduces costs, both lead arrangers and auditors might bring unique values to the participant banks. A reputable lead arranger facilitates ease of team collaboration and provides with better monitoring resources. Also, a reputable auditor adds value by improving the quality of financial statements, decreasing information costs, and asymmetry. Therefore, the study sheds some lights on for the borrowing firm about the significance of the relationship with reputable agents. It implies ties to reputable lead arrangers improve negotiating power of the borrower, to result in more favorable terms. Also, because of their unique values, reputable external auditors further improve the terms. For informationally disadvantaged participant banks, dual certification by different agents seems to add credits.

\section{THE LITERATURE AND HYPOTHESES DEVELOPMENT}

\section{Top Lead Arranger, and Loan Terms}

There is mixed evidence of top lead arranger's effect on loan spread, yet not many details on nonprice terms. The first line of the literature suggests that the ability of rent-seeking by reputable lenders. Cook et al. (2003) use various measures for reputation and find consistent results that reputable banks charge about 4.11 bps to 6.8 bps higher in loan spreads regardless of the choice of measures. Furthermore, they find that rent premiums are even elevated for opaque borrowers those may benefit most from the lead's certification role. For example, loan spread is significantly higher for small market capitalization, and junk-rated firms or non-secured loans. Similarly, Coleman et al. (2006) show that as the bank's monitoring ability increases the loan spread, as well as the maturity increases, in support of rent extraction. Also, in the bond market, Fang (2005) shows the significance of underwriting investment bank's reputation who charge higher premiums for high issue prices.

On the other hand, the second line of the literature suggests reputable banks benefit borrowers by charging a lower spread. Focarelli et al. (2008) find a positive certification effect by finding reduced interest spread as the lead arranger's retention increases. In case of opaque borrowers measured by their smaller total assets, the certification effect is even stronger. Also, Godlewski et al. (2012) use a measure of network density as a proxy for reputation and experience. They find that borrowers benefit from reduced loan spread in the presence of reputable lenders due to alleviated information asymmetry. They argue that it is possible because of high social capital and lower transaction costs when the network distance is shorter. For the project finance loans, Gatti et al. (2013) further validate the certification effect by showing decreased loan spread, but not the upfront fees with the presence of more prestigious lead arrangers. Their results imply that rather than the borrowers, it is other syndicate parties that pay the certification cost, in the form of lead arranger's upfront fee. Their results become even stronger during the financial crisis when the certification becomes more valuable.

\section{Certification Hypothesis}

Lead arranger's reputation can certify the borrower's credit quality to other, less informed stakeholders. Because reputation has capital value to the top lenders, who earned it over time by delivering high-quality services consistently. It identifies greater screening and due diligence efforts which significantly reduce adverse selections of low-quality borrowers ex-ante. At the same time, reputation suggests low moral hazard of credit monitoring ex-post loan issuances. Cheating at any point is costly for top lead arrangers. It may not only destroy their good names but also penalizes them in subsequent loan transactions when syndications are repetitive.

I argue that lead arranger's reputation as a signaling device is effective, and hard to imitate. When there is a low chance of cheating by top lead arrangers in their efforts, it increases chances of only highquality, yet informationally opaque borrowers to self-select. Low-quality borrowers cannot fake to be credible under robust due diligence, and monitoring of the reputable leads. Johnson (1997) supports the 
certification effect of reputation. He finds that the stock market reacted favorably to bank loan announcements, particularly when the bank is reputable. Similarly, Godlewski and Sanditov (2018) find positive reactions of loan announcement to the stock market. The result depends on the identity of the lender, and if the lender is more reputable, measured by its centrality, then the effect is substantial.

Therefore, in line with the second line of research, I hypothesize that the above certification effect benefits the borrower with more favorable loan terms. There could be at least two different channels that explain the association. First, the reputation increases trust in lead arrangers and makes collaboration much more manageable. Tykvová (2007) proposes a theoretical model where repeated relationships and reputation costs for the experienced lenders are main drivers for collaborative behaviors with less of cheatings. Similarly, evidence suggests that reputable banks have the comparative advantage of attracting other syndicate partners and possess strong negotiating power (Dennis \& Mullineaux, 2000; Lee \& Mullineaux, 2004). Meuleman et al. (2009) find that the reputation of lead arrangers help to form syndication more successfully for private equity lenders, encourage more collaborative behaviors, and reduce agency costs.

Second, monitoring cost is lower when reputable lead lenders arrange the syndicate. Monitoring cost is lower because of economies of scale, and scope they serve. Reputable lead banks not only can better identify systematic risks of the loan based on their experience, and skills but also, identify borrower idiosyncratic risks through their repeated relationships. Diamond (1991) highlights banks' unique ability to screen high-quality borrowers from bad quality ones due to their monitoring technology. Blackwell and Winters (1997) find the common practice of repeated lending, where borrowers benefit from reduced interest costs due to low information costs. Therefore, I hypothesize below:

H1: When a lead arranger is reputable, the borrower receives more favorable loan terms - a lower spread, a fewer number of covenants, greater loan amount, and longer maturity.

\section{Big 4 Auditor and Loan Terms}

Another form of certification by an independent third party, an external auditor, has been highly emphasized. Big $\mathrm{N}$ auditors could confirm the credibility of accounting information through its extensive monitoring. Big $\mathrm{N}$ reduces information costs, and increase trust in borrowers' financial numbers. Therefore, it increases borrowers' negotiating power, which might result in more favorable loan terms ceteris paribus. Kim et al. (2013) find that when the external auditor is one of the Big 4, the borrower receives reduced loan spread, and their results are stronger post-SOX period.

Furthermore, Chen et al. (2016) study the impact of the modified audit opinion on various loan terms. They find that borrowers with modified audit opinions pay higher loan interest rates, receive smaller loans for shorter periods, are constrained by covenants, and face stringent requirements on collateral. In contrast, Fortin and Pittman (2007) find no significant impact of auditor reputation on a bond spread for privately held companies. In addition to loan price terms, evidence suggests that Big 4 auditors favor nonprice terms. For example, El Ghoul et al. (2016) find that lenders extend loan maturity if the borrower's external auditor is one of the Big 4. Also, Karjalainen (2011) explores the cost of debt for private firms in Finland. He documents that auditor reputation is more crucial than both audit opinion and discretionary accruals in explaining loan interest rate.

\section{Cost Minimizing Hypothesis}

Lenders are privileged to have access to borrower's private information. Therefore, it is less obvious to see the value of external auditors' beyond that of top lead arrangers. However, as frequent users of financial statements, lenders highlight the importance of verification by Big name auditors. Loan officers take audit reports seriously and impair credit ratings effectively in case of going concern (Firth, 1980), or modified opinions (Bamber and Stratton, 1997). Particularly, lenders' take auditor's qualified opinion seriously if it is the opposite of their expectations. LaSalle and Anandarajan (1997) emphasize the importance of adverse disclaimers in the audit report in relevance to going concern and litigation uncertainty. Loan officers tend to issue adverse assessments of repayment and profitability based on the 
above information. They also document that loan officers charge a higher spread for above borrowers if they issue loans.

More recently, Guiral-Contreras et al. (2007) find that loan officers increase the loan ratings of firms if they believe that their financial information is credible. Also, Liu et al. (2018) find similar evidence for Chinese firms. Firms those get any type of adverse opinion, including going concern, qualified, or modified opinions are perceived as risky by lenders. Therefore, in such cases, lenders increase interest rates and shorten the loan maturity. Also, Francis et al. (2017) document that lenders credit auditor's tenure and respond to auditor turnovers. They find that lenders penalize an auditor turnover, especially if it happens with client initiation. Lenders increase the loan spread by about $22 \mathrm{bps}$, which is an additional cost of USD 6.6 million annually.

Above evidence suggest the material value of auditor's role in reducing lender's information costs, which lower credit risks. A high-quality auditor will help lenders to process due diligence in much efficient fashion because of better trust in the financial statement quality. Therefore, a syndicated loan team with cost minimizing objective shall differentiate auditor's identity, and react in favor of the borrower if one of the Big $\mathrm{N}$ audits it. Blackwell et al. (1998) argue that in the presence of assurance services, borrowers can reduce their loan costs, which is significantly beneficial to opaque firms. They document borrowers were able to lower their spread costs, by about 25 bps. Therefore, the second hypothesis is developed as below:

H2: The presence of borrower's reputable external auditor has a certification effect beyond that of reputable lead arranger by further lowering loan spread and the number of covenants and also increasing the loan amount and extending the maturity.

\section{MODEL DEVELOPMENT AND DATA}

\section{Empirical Model}

I construct below multiple regression model to test the hypotheses:

Loan terms $=\beta_{0}+\beta_{1}$ Top 10 lead $+\beta_{2}$ Big 4 auditor $+\beta_{3}$ Top 10 lead $*$ Big 4 auditor + $\theta$ Borrower controls $+\vartheta$ Loan purpose dummies $+\varepsilon$

I remove subscripts from the model for brevity. The dependent variable is any of loan price or nonprice terms. Top 10 lead dummy takes the value of one if any of the lead arrangers in the syndicate is a top 10 lender and zero otherwise. As for auditor's reputation, I create a dummy for a Big 4 auditor too. I predict that top 10 lenders have comparative advantages, thus provides a borrower with more favorable loan terms. Moreover, because high-quality auditors alleviate information asymmetry even further, I predict for significant and favorable coefficient estimates for Big 4 dummy. Therefore, I expect $\beta_{1}, \beta_{2}$, and $\beta_{3}$ to be statistically negatively significant for loan spread, the number of financial and general covenants indicating lower interest expense, less restrictions on both financial and general loan covenants. Also, I expect these parameter estimates to be positively significant for loan size and loan maturity to indicate a larger loan with longer time periods. Particularly, I am interested in the interaction term and expect $\beta_{3}$ to be economically and statistically significant after being added into the equation.

\section{Measuring Key Variables \\ Dependent Variables}

I use Thomson Reuter's Dealscan database to obtain my dependent variables, loan terms. Loan spread is a fixed rate over a floating reference rate (LIBOR, EURIBOR, etc.) and measured in basis points. The maturity is the number of days between facility end and facility start dates. Also, loan size is in millions of USD converted from foreign currency based on rates as of loan issuance dates. Finally, for each loan, I count the number of financial and general covenants. My sample consists of 10,105 unique loan facilities 
issued to 2,787 unique borrowers from 1996 to 2012. I exclude financial industries (SIC 6000 to 6999) and regulated industries (SIC 4000 to 4999).

\section{Measuring Top 10 Lead Arrangers}

Prior studies use different measures to identify the strength and resource of the lenders. The lender's S\&P credit ratings (Cook et al., 2003), market shares by volume of loan transactions (Gatti et al., 2013; Meuleman et al., 2009), the lead arranger retention (Ivashina, 2009), past lending relationships (Bharath, Dahiya, Saunders, \& Srinivasan, 2007) or top N dummy (Billett et al., 1995) to name some of the examples.

In syndicated loans lead arrangers' loan share could signal borrower's credit quality. Therefore, as the lead arranger's retention increases, loan interest spread decreases due to the certification effect (Ivashina, 2009). Do, and $\mathrm{Vu}$ (2010) confirm the validity of certification effect and further find evidence that the lead arranger reputation and past lender-borrower relationship can signal the borrower quality. More specifically, the significance of lead arranger retention on loan spread disappears for subsamples with a top 3 lead arranger or with previous loan relationships. In other words, their findings imply that for a top 3 lead arranger or a lead arranger who had past loan history with the borrower, it is not necessary to hold larger share to convince other loan partners. Instead, the top 3 lead arranger's reputation or the past relationship history could certify the quality of the borrower.

Dealscan reports "lead arranger credit" for all the lenders. I identify lead arrangers in the syndicated loan facility based on this variable. Next, for each lead lender, I count the number of loan facilities it arranged over my sample period from 1996 to 2012. Finally, I rank lead arrangers based on the number of facilities they have arranged during this period. Below is the list of the Top 10 lead arrangers.

TABLE 1

TOP 10 LEAD ARRANGERS

\begin{tabular}{|c|c|c|c|}
\hline № & Top 10 lead arrangers & $\begin{array}{l}\text { \# loan } \\
\text { facilities }\end{array}$ & $\begin{array}{l}\% \text { of loan facilities } \\
\text { in total facilities }\end{array}$ \\
\hline 1 & BANK OF AMERICA & 3,037 & 23.37 \\
\hline 2 & JP MORGAN & 2,828 & 21.76 \\
\hline 3 & CITI & 1,121 & 8.63 \\
\hline 4 & WELLS FARGO & 911 & 7.01 \\
\hline 5 & WACHOVIA & 589 & 4.53 \\
\hline 6 & DEUTSCHE BANK & 491 & 3.78 \\
\hline 7 & CREDIT SUISSE & 429 & 3.3 \\
\hline 8 & GE CAPITAL & 303 & 2.33 \\
\hline 9 & BNP PARIBAS & 279 & 2.15 \\
\hline 10 & SUNTRUST BANK & 253 & 1.95 \\
\hline & Total & 10,241 & 78.81 \\
\hline
\end{tabular}

As shown, Top 10 lead lenders arrange the majority of the transactions. Out of 12,996 lead lenderfacility transactions, Top 10 are involved in 10,241 facilities constituting $78.81 \%$ of the overall deals. Among those, Bank of America and JP Morgan are the two big players representing $23.37 \%$, and 21.76\% of the total loan transactions, respectively. 


\section{Measuring Auditor's Reputation}

DeAngelo 1981 first argued that the audit firm's size, which implies resources and capacities, could be a valid proxy for the audit's quality. Big 4 auditors serve the majority of the firms. In my sample, Big 4 auditors represent 81.4 percent of total observations. In the case of audit failures, the audit firm's reputation is damaged, thus loses its clients. The auditor's reputation cost is higher as the client base increases. The Big 4 is a standard measure to proxy auditor's reputation in the literature. I create a dummy variable that takes a value of one if the borrower's auditor is one of the big four auditors including Price Water House Coopers, Ernest \& Young, Deloitte \& Touche, and KPMG.

\section{Control Variables}

I control for various borrower's characteristics that could signal borrower's quality to the lenders, thus impact loan terms. More specifically, I include indebtedness measured by leverage, profitability measured by ROA, ability to repay the debt measured by interest coverage ratio, liquidity measured by current ratio, collateral measured by tangibility and other stability measures including cash flow volatility, market to book and total assets. Also, I include several dummies to control various loan purposes since loan terms could significantly change based on them.

TABLE 2

SUMMARY STATISTICS AND CORRELATIONS

\begin{tabular}{lrrrrrr}
\hline Panel A. Summary statistics & \multicolumn{7}{c}{ Mean } & \multicolumn{1}{c}{ Sd } & median & p25 & p75 \\
\hline \hline & $\mathrm{N}$ & & & & & \\
\hline Dependent variables & & & & & & \\
Spread & 10,105 & 218.22 & 140.79 & 200.00 & 125.00 & 275.00 \\
Loan size in millions of USD & 10,105 & 352.72 & 899.99 & 150.00 & 40.00 & 350.00 \\
Maturity in months & 10,105 & 47.64 & 22.40 & 51.77 & 36.43 & 60.90 \\
Financial covenants & 10,105 & 2.33 & 1.44 & 2.00 & 1.00 & 3.00 \\
General covenants & 10,105 & 2.42 & 2.31 & 1.00 & 1.00 & 5.00 \\
Research variables & & & & & & \\
Top 10 lead dummy & 10,105 & 0.68 & 0.47 & 1.00 & 0.00 & 1.00 \\
Big 4 & 10,105 & 0.82 & 0.39 & 1.00 & 1.00 & 1.00 \\
Control variables & & & & & & \\
Lender-borrower past rel-ship & 10,105 & 2.90 & 2.87 & 2.00 & 1.00 & 4.00 \\
Borrower size in millions of & & & & & & \\
USD & 10,105 & $3,800.60$ & $18,887.23$ & 823.98 & 237.73 & $2,669.48$ \\
Market to book & 10,105 & 3.02 & 3.90 & 2.00 & 1.25 & 3.26 \\
R\&D & 10,105 & 0.47 & 1.34 & 0.00 & 0.00 & 0.11 \\
Leverage & 10,105 & 0.28 & 0.18 & 0.27 & 0.15 & 0.40 \\
Profitability & 10,105 & 0.07 & 0.08 & 0.06 & 0.03 & 0.11 \\
Tangibility & 10,105 & 0.31 & 0.24 & 0.24 & 0.12 & 0.45 \\
Cash flow volatility & 10,105 & 0.09 & 0.21 & 0.03 & 0.01 & 0.07 \\
Current ratio & 10,105 & 1.95 & 1.45 & 1.66 & 1.19 & 2.31 \\
Interest coverage ratio & 10,105 & 0.02 & 0.05 & 0.00 & 0.00 & 0.01 \\
Macro control variables & & & & & & \\
Term spread & 10,105 & 1.73 & 1.24 & 1.74 & 0.56 & 2.95 \\
Credit spread & 10,105 & 0.99 & 0.38 & 0.90 & 0.79 & 1.13 \\
\hline
\end{tabular}




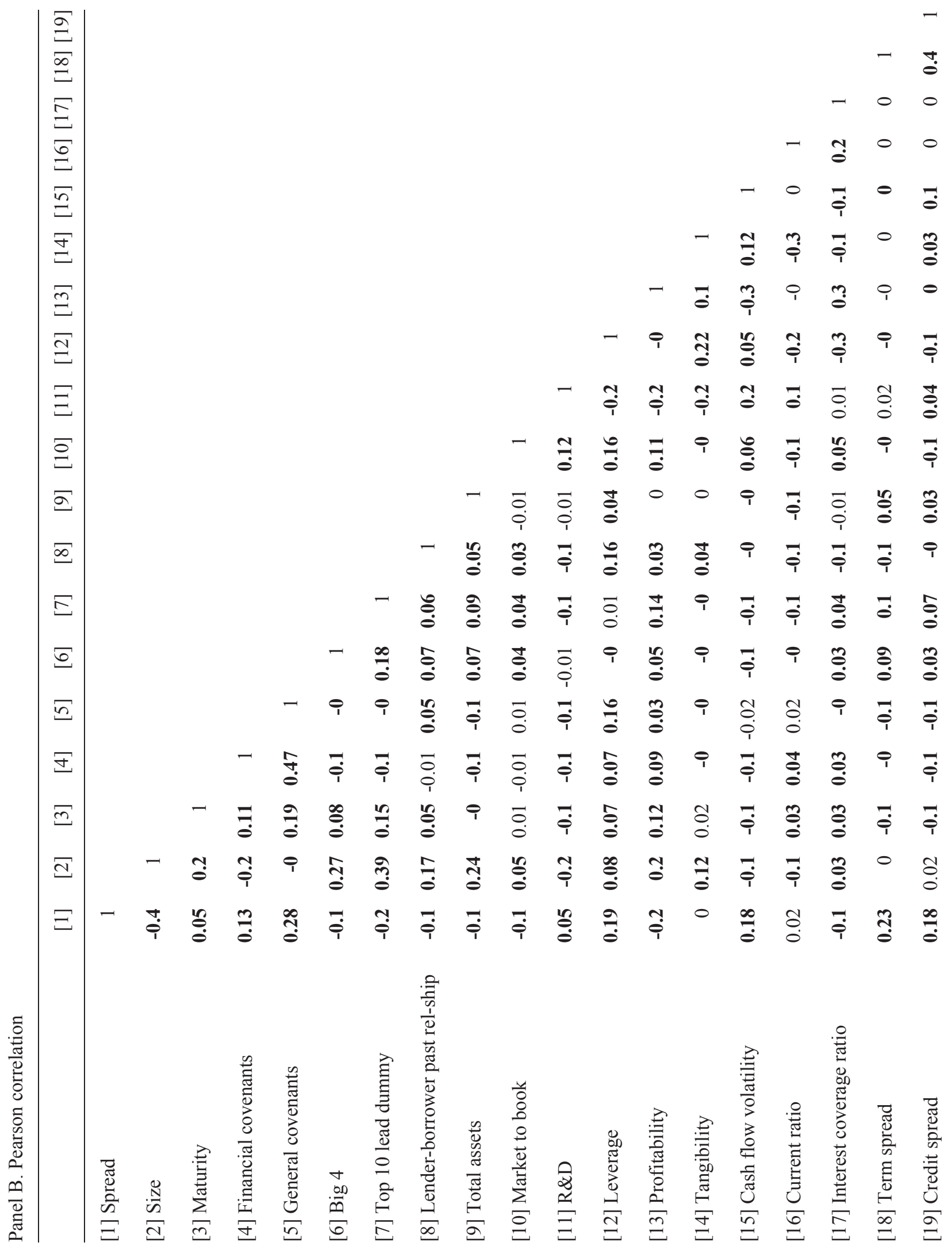


Also, because past loan relationship between lead arrangers and the borrower might impact future loan terms, I control for that following Bharath et al. (2007). I count the number of previous loan transactions between the same lead arranger and the borrower before the new loan issuance date. To alleviate reverse causality, I use lagged values for the borrower control variables. The loan terms are negotiated based on due diligence on past performances, thus such treatment is consistent with loan practice. Moreover, as macroeconomic factors, I include term and credit spreads. Also, I include industry fixed effects measured by the first two digits of the SIC.

Data

My sample comprises a total of 10,105 unique loan facilities from 1996 to 2012. Summary statistics and correlations of the variables are reported in Table 2 Panel A, and B, respectively. As shown above, an average loan facility is 352.72 million USD loans issued for about four years (47.64 months) with an interest rate of about 218.22bps (2.18\%) over a floating reference rate. Moreover, an average loan facility will dictate about two financial and two general covenants. After introducing control variables, Top 10 lead lenders arrange about 68 percent of facility transactions. However, loans are distributed unevenly among them, with 45 percent concentration on Top 2 lenders. Meuleman et al. (2009) argue that as the lender's centrality increases, its reputation matters the most due to the network effect with other banks. In such cases, honoring the responsibility is essential, and the lender must avoid damaging its reputation at any cost. Furthermore, Big 4 audits 82 percent of the borrowers. It looks common that the borrower seeks loans from the same lead arrangers it obtained loans in the past. Before the new loan facility start date, the same lead arranger and the borrower have involved in average about three loan transactions in the past, as shown in the summary statistics.

Also, borrower financial variables signal quality of the borrower, thus alleviate information asymmetry. The sample's average borrower size in terms of the total assets is about 3.8 billion USD, which is about 11 times larger than the average loan size. Most of the borrowing firms are growth firms as indicated by their high market to book ratio with a mean value of 3.02. Moreover, the leverage is only 28 percent of total assets for an average borrowing firm indicating lower indebtedness. The potential loan collateral measured by tangibility is 31 percent with a standard deviation of 24 percent for an average borrower. The borrower's loan repayment ability is measured by mean profitability (return on assets) of 7 percent, liquidity (current ratio) of 1.95 percent, interest coverage ratio of 2 percent, and cash flow volatility of 9 percent respectively.

As shown in Panel B correlations between the dependent variables and the key interested variables are highly significant with expected signs. More specifically, both Top 10 lead arranger and the borrower's Big 4 auditor have negative correlations with loan spread, the number financial and general covenants, and positive correlations with loan size and loan maturity. Moreover, most of the other control variables have significant correlations with the dependent variables to indicate their relevance for the analysis.

\section{MAIN RESULTS}

\section{Certification Effect Decreases Loan Spreads}

Table 3 reports the results of my main analysis. I find that when the lead arranger is a dominant bank in the syndicated loan, the borrower benefits from decreased interest costs indicated by a significant negative coefficient of 0.22 . Moreover, when I introduce the borrower's auditor choice measured by Big 4 auditor dummy, the Top 10 lead arranger dummy remains significant. Further, when the interaction of the two terms included in the equation, the interaction term is significantly negative while the two terms remain significant. Overall, results for loan spread from column 1 to 3 suggest that although either a dominant lead arranger or a Big 4 auditor brings value to the borrower in reducing the loan price, having both of them at the same time will decrease costs even further. 


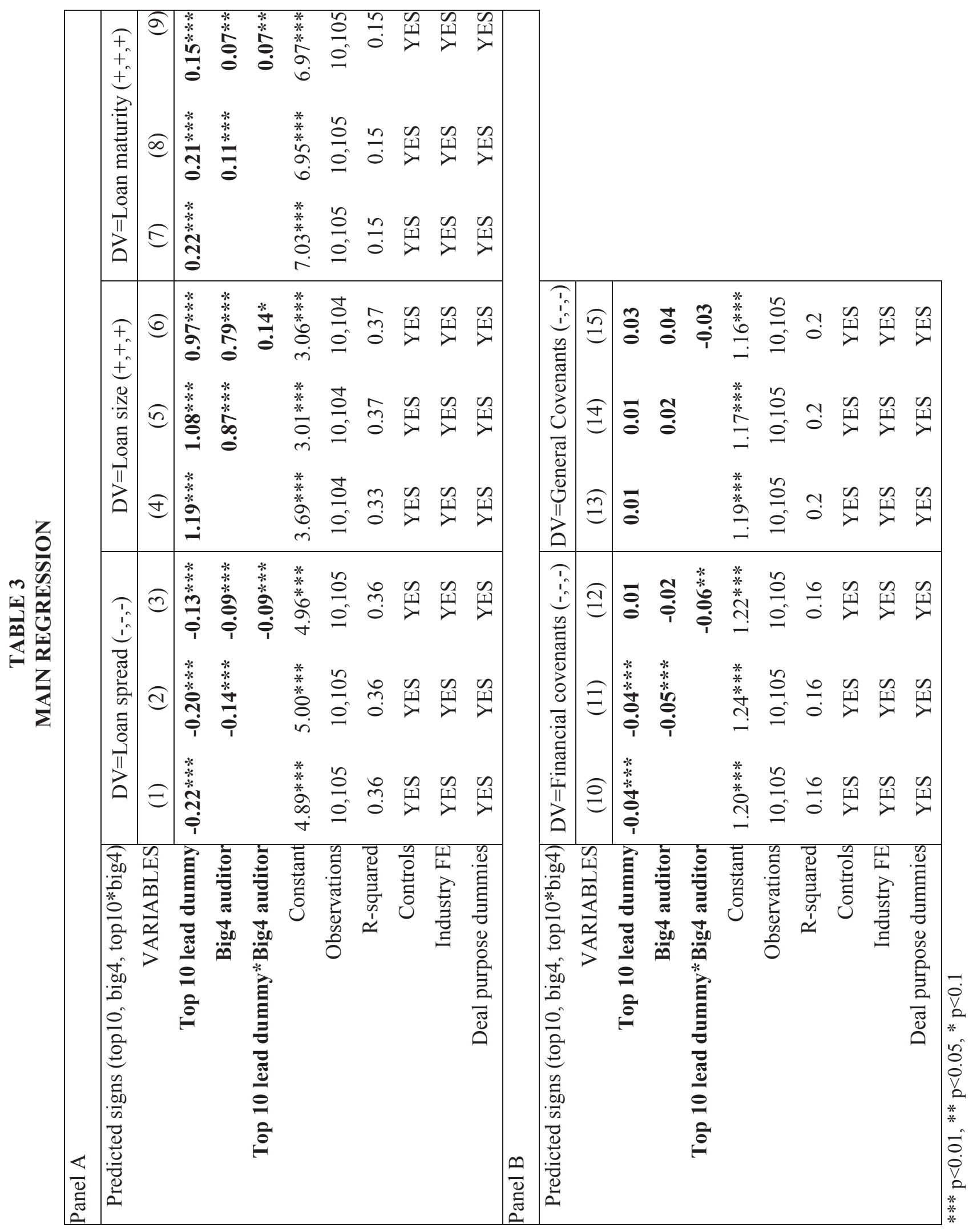


TABLE 4

SUMMARY OF MAIN RESULTS

\begin{tabular}{lcccc}
\hline Conditions & $\begin{array}{c}(1) \\
\text { Spread } \\
\text { (in bps) }\end{array}$ & $\begin{array}{c}\text { Amount } \\
\text { (in \$Mill) }\end{array}$ & $\begin{array}{c}\text { (3) } \\
\text { Maturity } \\
\text { (in years) }\end{array}$ & $\begin{array}{c}\text { Fin_Cov } \\
\text { (in numbers) }\end{array}$ \\
\hline \hline Top10=0; Big4=0 & 141.59 & 21.33 & 2.92 & 3.39 \\
Top10=1; Big4=0 & 125.21 & 56.26 & 3.39 & - \\
Top10=0; Big4=1 & 130.32 & 46.99 & 3.13 & 3.19 \\
Top 10=1; Big4=1 & 104.58 & 142.59 & 3.90 & \\
\hline
\end{tabular}

In Table 4, I report results in non-logged units for the convenience of interpretation since all dependent variables are in natural logarithm form. Column 1 represents the results for the interaction term on loan spread. As shown above, borrowers without any relationships with reputable agents pay about $141.59 \mathrm{bps}$ over the floating interest rate after controlling for their other risk factors. However, changing from a non-Top 10 lead arranger to a Top 10 lead arranger would reduce their interest cost by about 16.38 bps. Similarly, having a Big 4 auditor would decrease interest cost by about 11.27 bps. Most importantly, having both Top 10 lead arranger and a Big 4 auditor at the same time would reduce interest costs significantly by about $37 \mathrm{bps}$. That is for an average loan of 350 million dollars the borrower can save 1.3 million dollars annually in interest costs.

\section{Certification Effect Increases Loan Amounts}

As for loan amount, borrowers without any relationships with reputable agents get an average of 21.33 million dollars from the syndication. However, as they switch from a non-Big 4 auditor to a Big 4 auditor, their loan amount increases to 46.99 million dollars, which is an increase of more than two times. If the borrower obtains the loan from a Top 10 lead arranger, the loan amount increases even more to 56.26 million dollars due to the Top 10 lead arranger's reputation, and resource capacity. The presence of both Big 4 auditor and a Top 10 lead arranger significantly increases the average loan amount by about 35 percent resulting in loan of 142.59 million dollars. Both a reputable external auditor and a dominant lead arranger alleviate information asymmetry for the syndicate participants to signal the borrower's credibility. Therefore, thanks to the enhanced certification effect, it is easier to collect funds from other participants.

\section{Certification Effect Increases Loan Maturity}

I find a positive impact of certification effect on loan maturity and report the results in Table 3 , and Table 4. The borrower, with no relationships with reputable agents, receives loans for 2.9 years on average. However, the presence of a Top 10 lead arranger extends the loan maturity materially by about a half year to 3.4 years. In column 8, a significant positive coefficient of 0.11 indicates that a Big 4 external auditor adds value beyond that of a Top 10 lead arranger with marginal information value. Further, when I take the interaction of the two terms, it is positively significant, while maintaining significances of each of them. In fact, after converting the parameter estimates to non-logarithm form in Table 4 column 3, loan maturity extends by about a year when the borrower has both a Top 10 lead arranger and a Big 4 external auditor. 


\section{Certification Effect Decreases The Number of Financial Covenants}

As for the number of financial covenants, while the dominant lead arranger and the Big 4 certification effects are significant in separate, they lose significances when the interaction term is introduced. In column 12, the interaction term is significantly negative, implying the positive effect of certification. More specifically, having both the dominant lead arranger and the reputable external auditor in average decreases the number of financial covenants by 0.2 . Moreover, as for the number of general covenants, as shown in column 13-15 of Table 3, the certification effect no longer holds neither for a dominant lead arranger nor for a Big 4 external auditor. Although the interaction term is negative, it loses its statistical significance. Overall, the results suggest that as compared to other loan terms, covenants are hard to negotiate.

Above results have practical implications on borrower's loan application, as well as auditor hiring decisions. In syndicated loans, participant banks are at informationally disadvantaged positions due to their passive roles. Therefore, borrowers' relationships with reputable agents alleviate information asymmetry and help borrowers to receive more favorable loan terms. Whom to tie relationships matters. If the borrowing firm could build relationships with reputable, yet different agents, the certification effect can be enhanced.

\section{ROBUSTNESS TESTS}

\section{TABLE 5}

\section{ROBUSTNESS TEST: COMPARISON WITH SUR ESTIMATION METHOD}

Panel A: Baseline results

\begin{tabular}{|l|c|c|c|c|c|}
\hline & Spread & Amount & Maturity & Fin_Cov & Gen_cov \\
\hline VARIABLES & $(3)$ & $(6)$ & $(9)$ & $(12)$ & $(15)$ \\
\hline & & & & \\
Top 10 lead dummy & $-0.13^{* * *}$ & $0.97 * * *$ & $0.15^{* * *}$ & 0.01 & 0.03 \\
Big4 auditor & $-0.09 * * *$ & $0.79 * * *$ & $\mathbf{0 . 0 7 * *}$ & -0.02 & 0.04 \\
Top 10 lead dummy*Big4 & $-0.09 * * *$ & $\mathbf{0 . 1 4 *}$ & $\mathbf{0 . 0 7 * *}$ & $\mathbf{- 0 . 0 6 * *}$ & -0.03 \\
auditor & YES & YES & YES & YES & YES \\
Control variables & $4.96^{* * *}$ & $3.06 * * *$ & $6.97 * * *$ & $1.22 * * *$ & $1.16^{* * *}$ \\
Constant & \multicolumn{7}{c}{} \\
\hline
\end{tabular}

Panel B: SUR results

\begin{tabular}{|l|c|c|c|c|c|}
\hline & Spread & Amount & Maturity & Fin_Cov & Gen_cov \\
\cline { 2 - 6 } & $(3)$ & $(6)$ & $(9)$ & $(12)$ & $(15)$ \\
\hline & & & & & \\
VARIABLES & & & \\
Big4 lead dummy & $-0.13 * * *$ & $0.97 * * *$ & $0.15^{* * *}$ & 0.01 & 0.03 \\
Top 10 lead dummy*Big4 & $-0.09 * * *$ & $0.79 * * *$ & $\mathbf{0 . 0 7 * * *}$ & -0.02 & 0.04 \\
auditor & $-0.09 * * *$ & $\mathbf{0 . 1 4 * *}$ & $\mathbf{0 . 0 7 * * *}$ & $\mathbf{- 0 . 0 6 * * *}$ & -0.03 \\
Control variables & YES & YES & YES & YES & YES \\
Constant & $4.96^{* * *}$ & $3.06 * * *$ & $6.97 * * *$ & $1.22 * * *$ & $1.16^{* * *}$ \\
\hline
\end{tabular}

\section{Alternative Estimation Method}

In my baseline analysis, I did not consider plausible correlations among dependent variables. However, in practice, loan terms are negotiated as a set. So do the Pearson's correlations in Table 2 Panel B indicate highly significant correlations among the dependent variables. Depending on the loan amount, 
the interest rate could change due to economies of scale impact. Strahan (2000) finds that loan price significantly relates to other non-price terms. As the loan spread increases, loan amount decreases, and maturity shortens. Therefore, ignoring correlations among equations in the baseline analysis could introduce significant bias to the results. I rerun the analyses using seemingly unrelated equation (SUR) following Zellner (1962), which allows correlations among dependent variables.

The results from these analyses are represented in Table 5 Panel B and compared with the baseline results in Panel A. Since only the assumption on error terms has changed, the parameter estimates remain the same as in the baseline case, but the statistical significances change due to changes in standard errors. As shown above, with SUR specification, the statistical significances of the interaction term between the dominant lead arranger and the Big 4 auditor improve for the loan amount, maturity, and financial covenant. I conclude that with an alternative SUR estimation method, baseline results hold even stronger.

\section{Alternative Measures for Certification}

As an alternative measure, I identify the Top 10 lead arrangers based on their syndicated loan volume instead of the number of deals they arrange. The results hold with this alternative specification. In addition to that rather than Big 4 auditor dummy, I create a dummy for Big 6 auditors. In unreported analyses, results hold even stronger.

\section{CONCLUSION}

Previous studies suggest the certification role of reputed lenders showing a positive impact on borrower's stock market returns. With evidence of the syndicated loan, I test the certification effect of lead arranger's reputation on loan price, and non-price terms. My results suggest the information value of reputable lead arrangers. In the presence of reputable lead arrangers, borrowers receive lower interest spread, a fewer number of financial covenants, and increased loan amount, with extended loan maturity. Moreover, I find that external auditor could certify beyond that of lead arranger's reputation by further adding value to the borrower. In complex cases of syndicated loans where information asymmetry is nonuniform across lenders, dual certification by different bodies seems to help. Relationships with both reputable lead arrangers and external auditors substantially increase borrowers' negotiating power to result in more favorable terms. However, the current study is limited to estimate gross benefits only without addressing potential premium fees of Big 4 auditors. When looking at loan price only, Blackwell et al. (1998) document interest savings from Big 4 are not high enough to cover their premium fees.

\section{REFERENCES}

Bamber, E. M., \& Stratton, R. A. (1997). The Information Content of the Uncertainty-Modified Audit Report: Evidence from Bank Loan Officers. Accounting Horizons : A Quarterly Publication of the American Accounting Association, 11(2).

Beatty, R. P., \& Ritter, J. R. (1986). Investment banking, reputation, and the underpricing of initial public offerings. Journal of Financial Economics, 15(1-2), 213-232. http://doi.org/10.1016/0304405X(86)90055-3

Bharath, S., Dahiya, S., Saunders, A., \& Srinivasan, A. (2007). So what do I get? The bank's view of lending relationships. Journal of Financial Economics, 85(2), 368-419. http://doi.org/10.1016/J.JFINECO.2005.08.003

Billett, M. T., Flannery, M. J., \& Garfinkel, J. A. (1995). The Effect of Lender Identity on a Borrowing Firm's Equity Return. The Journal of Finance, 50(2), 699. http://doi.org/10.2307/2329425

Blackwell, D. W., Noland, T. R., \& Winters, D. B. (1998). The Value of Auditor Assurance: Evidence from Loan Pricing. Journal of Accounting Research, 36(1), 57. http://doi.org/10.2307/2491320

Blackwell, D. W., \& Winters, D. B. (1997). Banking Relationships and The Effect of Monitoring on Loan Pricing. Journal of Financial Research, 20(2), 275-289. http://doi.org/10.1111/j.14756803.1997.tb00249.x 
Carter, R., \& Manaster, S. (1990). Initial Public Offerings and Underwriter Reputation. The Journal of Finance, 45(4), 1045-1067. http://doi.org/10.1111/j.1540-6261.1990.tb02426.x

Cen, L., Dasgupta, S., Elkamhi, R., \& Pungaliya, R. S. (2016). Reputation and Loan Contract Terms: The Role of Principal Customers *. Review of Finance, 20(2), 501-533. http://doi.org/10.1093/rof/rfv014

Chen, P. F., He, S., Ma, Z., \& Stice, D. (2016). The information role of audit opinions in debt contracting. Journal of Accounting and Economics, 61(1), 121-144. http://doi.org/10.1016/J.JACCECO.2015.04.002

Chin, C.-L., Yao, W.-R., \& Liu, P.-Y. (2014). Industry Audit Experts and Ownership Structure in the Syndicated Loan Market: At the Firm and Partner Levels. Accounting Horizons, 28(4), 749-768. http://doi.org/10.2308/acch-50825

Coleman, A. D. F., Esho, N., \& Sharpe, I. G. (2006). Does bank monitoring influence loan contract terms? Journal of Financial Services Research, 30(2), 177-198. http://doi.org/10.1007/s10693006-0017-5

Cook, D. O., Schellhorn, C. D., \& Spellman, L. J. (2003). Lender certification premiums. Journal of Banking and Finance, 27(8), 1561-1579. http://doi.org/10.1016/S0378-4266(02)00278-9

Dennis, S. A., \& Mullineaux, D. J. (2000). Syndicated Loans. Journal of Financial Intermediation, 9(4), 404-426. http://doi.org/10.1006/jfin.2000.0298

Diamond, D. W. (1991). Monitoring and Reputation: The Choice between Bank Loans and Directly Placed Debt. Journal of Political Economy, 99(4), 689-721. http://doi.org/10.1086/261775

Do, V., \& Vu, T. (2010). The effects of reputation and relationships on lead banks' certification roles. Journal of International Financial Markets, Institutions and Money, 20(5), 475-489. http://doi.org/10.1016/j.intfin.2010.06.005

El Ghoul, S., Guedhami, O., Pittman, J. A., \& Rizeanu, S. (2016). Cross-Country Evidence on the Importance of Auditor Choice to Corporate Debt Maturity. Contemporary Accounting Research, 33(2), 718-751.

Fang, L. H. (2005). Investment Bank Reputation and the Price and Quality of Underwriting Services. The Journal of Finance, 60(6), 2729-2761. http://doi.org/10.1111/j.1540-6261.2005.00815.x

Firth, M. (1980). A note on the impact of audit qualifications on lending and credit decisions. Journal of Banking \& Finance, 4(3), 257-267. http://doi.org/10.1016/0378-4266(80)90023-0

Focarelli, D., Pozzolo, A. F., \& Casolaro, L. (2008). The pricing effect of certification on syndicated loans. Journal of Monetary Economics, 55(2), 335-349. http://doi.org/10.1016/j.jmoneco.2007.11.004

Fortin, S., \& Pittman, J. a. (2007). The Role of Auditor Choice in Debt Pricing in Private Firms. Contemporary Accounting Research, 24(3), 859-896. http://doi.org/10.1506/car.24.3.8

Francis, B. B., Hunter, D. M., Robinson, D. M., Robinson, M. N., \& Yuan, X. (2017). Auditor Changes and the Cost of Bank Debt. The Accounting Review, 92(3), 155-184. http://doi.org/10.2308/accr51553

Gatti, S., Kleimeier, S., Megginson, W., \& Steffanoni, A. (2013). Arranger Certification in Project Finance. Financial Management, 42(1), 1-40. http://doi.org/10.1111/j.1755-053X.2012.01210.x

Gilson, S. C., \& Warner, J. B. (1998). Private Versus Public Debt: Evidence From Firms That Replace Bank Loans With Junk Bonds. SSRN Electronic Journal. http://doi.org/10.2139/ssrn.140093

Godlewski, C. J., \& Sanditov, B. (2018). Financial Institutions Network and the Certification Value of Bank Loans. Financial Management, 47(2), 253-283. http://doi.org/10.1111/fima.12197

Godlewski, C. J., Sanditov, B., \& Burger-Helmchen, T. (2012). Bank Lending Networks, Experience, Reputation, and Borrowing Costs: Empirical Evidence from the French Syndicated Lending Market. Journal of Business Finance and Accounting, 39(1-2), 113-140. http://doi.org/10.1111/j.1468-5957.2011.02269.x

Guiral-Contreras, A., Gonzalo-Angulo, J. A., \& Rodgers, W. (2007). Information content and recency effect of the audit report in loan rating decisions. Accounting \& Finance, 47(2), 285-304. http://doi.org/10.1111/j.1467-629X.2006.00208.x 
Ivashina, V. (2009). Asymmetric information effects on loan spreads. Journal of Financial Economics, 92(2), 300-319. http://doi.org/10.1016/j.jfineco.2008.06.003

James, C. (1987). Some evidence on the uniqueness of bank loans. Journal of Financial Economics, 19(2), 217-235. http://doi.org/10.1016/0304-405X(87)90003-1

Johnson, S. A. (1997). The Effect of Bank Reputation on the Value of Bank Loan Agreements. Journal of Accounting, Auditing \& Finance, 12(1), 83-100. http://doi.org/10.1177/0148558X9701200105

Karjalainen, J. (2011). Audit Quality and Cost of Debt Capital for Private Firms: Evidence from Finland. International Journal of Auditing, 15(1), 88-108. http://doi.org/10.1111/j.10991123.2010.00424.x

Kim, J.-B., \& Song, B. Y. (2011). Auditor Quality and Loan Syndicate Structure. AUDITING: A Journal of Practice \& Theory, 30(4), 71-99. http://doi.org/10.2308/ajpt-10144

Kim, J. B., Song, B. Y., \& Tsui, J. S. L. (2013). Auditor size, tenure, and bank loan pricing. Review of Quantitative Finance and Accounting, 40(1), 75-99. http://doi.org/10.1007/s11156-011-0270-z

LaSalle, R. E., \& Anandarajan, A. (1997). Bank Loan Officers' Reactions to Audit Reports Issued to Entities with Litigation and Going Concern Uncertainties. Accounting Horizons : A Quarterly Publication of the American Accounting Association, 11(2).

Lee, S. W., \& Mullineaux, D. J. (2004). Monitoring, Financial Distress, and the Structure of Commercial Lending Syndicates. Financial Management, 33(3), 107-130. Retrieved from http://www.jstor.org/stable/3666266

Liu, H., Cullinan, C. P., \& Zhang, J. (2018). Modified audit opinions and debt contracting: evidence from China. Asia-Pacific Journal of Accounting \& Economics, 1-24. http://doi.org/10.1080/16081625.2018.1517048

Lummer, S. L., \& McConnell, J. J. (1989). Further evidence on the bank lending process and the capitalmarket response to bank loan agreements. Journal of Financial Economics, 25(1), 99-122. http://doi.org/10.1016/0304-405X(89)90098-6

McCahery, J., \& Schwienbacher, A. (2010). Bank reputation in the private debt market. Journal of Corporate Finance, 16(4), 498-515. http://doi.org/10.1016/j.jcorpfin.2010.04.002

Meuleman, M., Wright, M., Manigart, S., \& Lockett, A. (2009). Private Equity Syndication: Agency Costs, Reputation and Collaboration. Journal of Business Finance \& Accounting, 36(5-6), 616644. http://doi.org/10.1111/j.1468-5957.2009.02124.x

Ross, D. G. (2010). The "Dominant Bank Effect:" How high lender reputation affects the information content and terms of bank loans. Review of Financial Studies, 23(7), 2730-2756.

Slovin, M. B., Johnson, S. A., \& Glascock, J. L. (1992). Firm size and the information content of bank loan announcements. Journal of Banking \& Finance, 16(6), 1057-1071. http://doi.org/10.1016/0378-4266(92)90059-9

Strahan, P. E. (2000). Borrower Risk and the Price and Nonprice Terms of Bank Loans. SSRN Electronic Journal. http://doi.org/10.2139/ssrn.192769

Sundarasen, S. D., Khan, A., \& Rajangam, N. (2018). Signalling Roles of Prestigious Auditors and Underwriters in an Emerging IPO Market. Global Business Review, 19(1), 69-84. http://doi.org/10.1177/0972150917713367

Tykvová, T. (2007). Who chooses whom? Syndication, skills and reputation. Review of Financial Economics, 16(1), 5-28. http://doi.org/10.1016/J.RFE.2005.10.001

Zellner, A. (1962). An Efficient Method of Estimating Seemingly Unrelated Regressions and Tests for Aggregation Bias. Journal of the American Statistical Association, 57(298), 348. http://doi.org/10.2307/2281644

54 Journal of Applied Business and Economics Vol. 21(5) 2019 